\title{
The Woman Who Made Hollywood
}

\author{
By Roy Schwartzman
}

Fall 1997 Issue of KINEMA

THE great motion pictures of the silent era unseen by generations which have known only "talking pictures" had about them an unforgettable hypnotic, luminous quality that held audiences in thrall. Tales of heroic characters whose lives were caught up in adventure, adversity, and romance -- where the poor were put upon but valiant and the rich provided satisfactions to be strived for -- captured the imagination of audiences everywhere who suffered and triumphed along with their favourite players whom they loved and adored.

It was the mysterious attraction of the lives depicted on the silent screen that touched their emotions and made them laugh and cry. The lovely and handsome faces of the actors and actresses shone forth in beautiful black-and-white photography like stars in the night sky. From this beauty, set within comedies and dramas, the term "star" and "star power" came into being through the language of film; and no star was brighter than Mary Pickford. When the writer Adela Rogers St. Johns wrote that throughout her career Mary Pickford was "The best known woman who has ever lived, the woman who was known to more people and loved by more people than any other woman that has been in all history" she did not exaggerate.

At the height of their fame Mary Pickford, Douglas Fairbanks and Charlie Chaplin commanded worldwide audiences. When they travelled across North America, to London and to the capitals of Europe, their admirers turned out not in their thousands but in their millions. But more than seventy years have passed since then and sadly, of the famous three, only Chaplin is remembered. All the more reason then to welcome this affectionate, thorough and comprehensive, yet unblinking biography of Mary Pickford by Eileen Whitfield.

Mary Pickford was born in Toronto but was known internationally as "America's Sweetheart". Born and brought up in poverty she became so wealthy that Chaplin called her "the Bank of America's Sweetheart". While Mary's heart always belonged to Douglas Fairbanks, and whose life together is one of this century's most beautiful and tragic romances, she and Chaplin had much in common by having similar social and family environment, Chaplin in London, Pickford in Toronto. Although Fairbanks, (The Thief of Bagdad, The Black Pirate) and Chaplin were always the closest of friends, Pickford was never fond of Chaplin. Only business affairs and dinner parties brought them together -- at a distance and over often furious arguments about their films and finances, particularly during the time when they owned United Artists along with D.W. Griffith.

Born Gladys Marie Smith in 1892 at 211 University Avenue (an historic plaque marks the spot) where the Hospital for Sick Children now stands, she was one of three children brought up by a courageous mother when her loving but alcoholic father died in an accident when Gladys was six years old, Her happy memories "ended then".

She was eight years old when her career began in January 1900, performing on the stage of the Princess Theatre on King Street in The Silver King. For the next nine years she appeared in vaudeville houses, at the Royal Alexandra, and spending weary, grimy years sleeping on trains and living in horrible boarding houses across Canada and the US. All was melodrama: Pickford identified with the poor, with victims, suffering and starving children in threadbare clothes, goodness pitted against the wicked. She learned her craft slowly becoming a consummate and knowing actress. One of her greatest successes was as "Little Eva" in Uncle Tom's Cabin.

By 1909 however, more people were going to the movies than to theatres. Reluctantly, because all actors considered working in films to be the lowest form of endeavour although they relished earning five dollars a day -- she went to the Biography studios and met the soon-to-be-great director, D.W. Griffith. She stayed with him until 1913, turning out hundreds of short films. Her initial dislike of the nickel-odeons turned to love and enthusiasm; she mastered the techniques and learned how to express herself and delineate character for the cameras. Together with Lilian Gish, Mary Pickford became the most popular among screen stars. She turned to full-length films in 1913 and made over fifty, ending her career in 1933 with Secrets -- and 
beginning her long addiction to alcohol. She felt her work had become meaningless and left her films to disintegrate in their cans. She died in 1979.

Among her most famous pictures are Tess of the Storm Country, Cinderella, Rags, The Poor Little Rich Girl, Rebecca of Sunny Brook Farm, Stella Maris, Daddy-Long-Legs, Pollyanna, Little Lord Fauntleroy, Sparrows, My Best Girl, to name only a few which brought her immense and loyal audiences. She started in features with Adolph Zukor, who starred her in his Famous Players Film Company productions, forming her own company, the Mary Pickford Corporation, in 1916.

The practice of certain biographers attributing childhood surroundings, relationships and behaviour to their subjects' screen persona is frequently stretched to incredulity; but Eileen Whitfield takes us through Pickford's films and the crises in her career showing how her many years of struggle, emotional turmoil, guilt and despair, made it possible for her to understand and relate to the heroines she portrayed. She almost always played the elder child and she did this with uncanny naturalism -- because she never forgot what it was like to be a child. More than this Pickford was a fighter; she stood up and defended the characters she played and went to the aid of the oppressed and down-trodden.

Throughout her study Eileen Whitfield gives us a compellingly restored picture of what it was like working during the silent period. When sound came in Mary Pickford knew her roles had to change and cut off her long and beautiful hair. Her public was appalled; it marked the end of an era.

This fascinating biography took ten years to complete with research combining hundreds of "pieces" from books, magazines, newspapers, interviews and conversations. Placed within the author's imaginative and sympathetic text they bring together the alternately joyful and troubled life of Mary Pickford -- in her Camelot known as Pickfair.

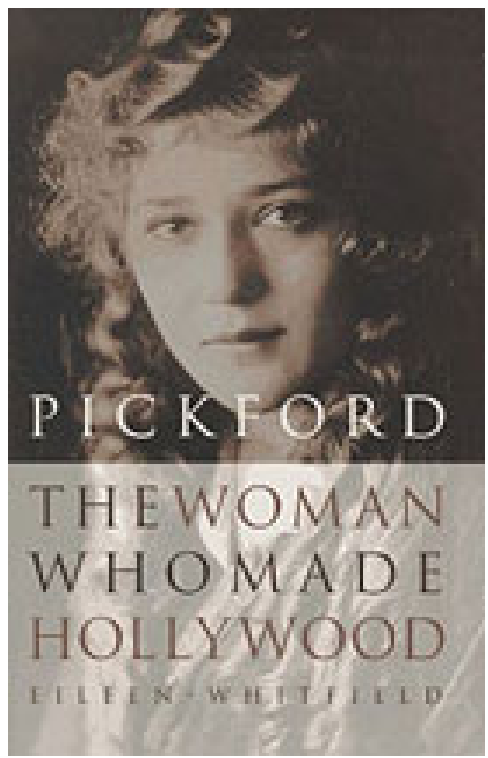

Figure 1: AUTHOR: Eileen Whitfield 9 COUNTRY: Canada 9 PUBLISHER: Macfarlane Walter \& Ross, and Univ. of Kentucky ๆ YEAR OF RELEASE: 1997 ๆ PAGES: 427pp ๆ ISBN: 0813120454 ๆ PRICE: USD 25.00 (cloth)

\section{Author Information}

Roy SCHWARTZMAN is Associate Professor of Communication and Basic Course Coordinator at Northwest Missouri State University. He has designed and taught courses in science-fiction film. His research interests include the rhetorical uses of science, especially the use of science to support racism and anti-Semitism in Nazi Germany. 